\title{
Design and Manufacture Three Solar Distillation Units and Measuring Their Productivity
}

\author{
Rusul Dawood Salim ${ }^{1}$, Jassim Mahdi AL-Asadi ${ }^{1}$, Aqeel Yousif Hashim ${ }^{2}$ \\ ${ }^{1}$ Physics Department, College of Education, University of Basrah, Basrah, Iraq \\ ${ }^{2}$ Technical institute of Basrah, Southern Technical University, Basrah, Iraq
}

Email address:

Rosalh7975@Gmail.com (R. D. Salim)

\section{To cite this article:}

Rusul Dawood Salim, Jassim Mahdi AL-Asadi, Aqeel Yousif Hashim. Design and Manufacture Three Solar Distillation Units and Measuring Their Productivity. Science Journal of Energy Engineering. Vol. 3, No. 2, 2015, pp. 6-10. doi: 10.11648/j.sjee.20150302.11

\begin{abstract}
In this research, a comparison is made among three units of solar water distillation (M1, M2 and M3), where M1 is a passive solar still , M2 is a passive solar still coupled with flat plate collector and M3 is similar to M2 but it was provided with copper tube inside the still to realize the latent heat. Only the daily productivity factor was used to make a comparison among these units. The results shows that the productivity of M2 is more than it for M1 by $42 \%$, While the productivity of M3 is more than it of $\mathrm{M} 1$ by $52 \%$.
\end{abstract}

Keywords: Solar Collector, Solar Energy, Solar Distillation, Solar Water Heating, Solar Still

\section{Introduction}

Searching the energy sources become the main issue in the world, environmental pollution encoding world to search for clean energy sources, the sun is the most important source of make clean energy so that solar radiation can be transformed through systems and equipments which innovated by scholars and researchers it can be invested in different fields in the factories, domiciles and academic institutions, etc.

The need of clean, pure drinkable water in many countries. Often water sources are brackish and or contain harmful bacteria and therefore cannot be used for drinking. In addition, there are many coastal locations where seawater is abundant but potable water is not available. Pure water is also needful in some industries, hospitals and schools. Distillation is one of many processes that can be used for water purification. Solar radiation can be the source of heat energy. In this process, water is evaporated and thus separating water vapour from dissolved substances, and is then condensed as pure water [1] .

The process for solar distillation in common with all other process of distillation as well as evaporation and condensation process, but it differ from other energy production processes in terms of not having to recurrence costs, and the major cost of this process can be included in the cost of solar collectors.

Solar still is characterized by having simple design, installation and maintenance as well as the ease of operation. Research has indicated that solar stills has an economic use to provide small amounts of water in the same time it can be expensive to produce water for an arid region.

The glass has the property of transmitting incident shortwave solar radiation which passes through the glass, the glass being a medium of transfer of heat, into the still to heat the brine. However, the re-radiated wavelengths from the heated water surface are infra-red and very little of it is transmitted back through the glass as it is shown in figure (1).

Water is an abundant natural resource that covers three quarters of the earth's surface. However, around $97 \%$ of the water in the world is in the ocean, only about $3 \%$ of all water sources are potable. Less than $1 \%$ fresh water is available within human reach and even this small fraction (ground water, lakes and rivers) is believed to be adequate to support life and vegetation on the earth and the rest is permanent snow cover, ice and permafrost in polar region. About $25 \%$ of the world does not have access to good quality and quantity of fresh water and more than 80 countries face severe water problem [3].

The rapid increasing need for energy and environmental concerns has focused much attention on renewable energy resources. Nowadays pollution in rivers and lakes by industrial effluents and sewage disposal has resulted in scarcity of fresh water in many big cities around the world [4].

The use of solar energy is more economical than the use of 
fossil fuel in remote areas having low population densities, low rain fall and abundant available solar energy. Solar stills are highly reliable and they can easily provide us with the necessary daily amount of drinking water for the water scare and drought areas. Also it is simple and has no moving parts and maintenance free. The problem of solar stills is the low productivity. Different techniques were used to enhance the output of the stills.[5].

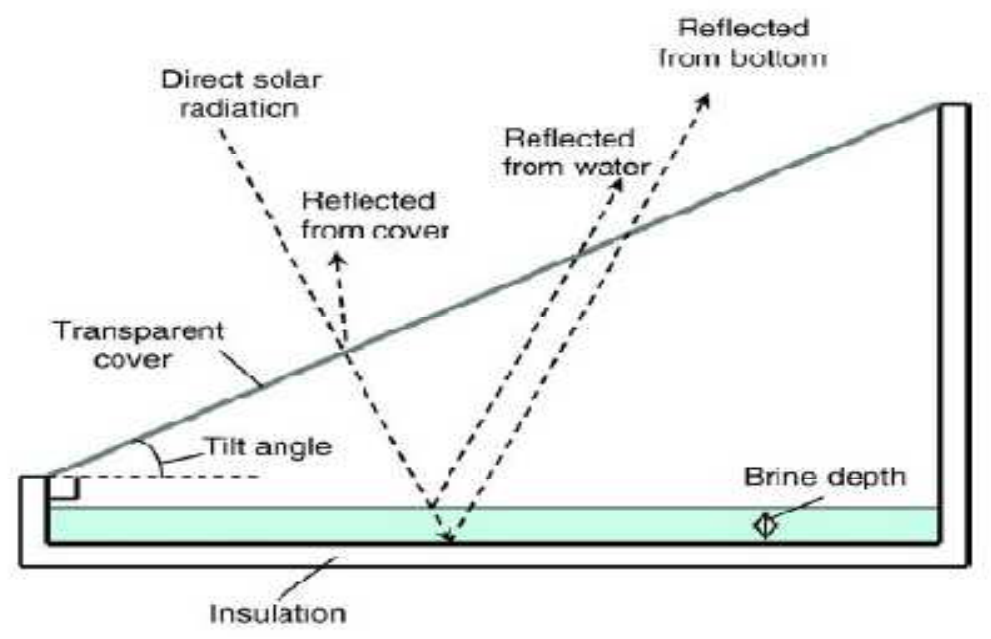

Fig (1). Schematic diagram of a basin-type solar still [2].

Solar energy desalination is generally the collecting of solar thermal energy that is used for desalination directly in solar still or indirectly (solar collector, photovoltaic (PV), ... etc.) [6].

Solar distillation is one of many processes that can be used to produce fresh water by using the heat of the sun directly in a simple equipment to purify water. The equipment, commonly called a solar still [7]. Solar stills are more attractive for smaller required output than the other techniques of desalination [8].

An experimental investigation on a solar still with an integrated flat plate collector was studied. Rajaseenivasan et al Experiments are carried out by varying the water depth in the basin and using the wick and energy storing materials in basins of both stills. The flat plat collector coupled with basins still gives about $60 \%$ higher distillate than the conventional still for the same basin condition. Economic analysis shows that the cost of distilled water for the FPCB still is lower than that for the conventional still $[9,10]$.

The general objective of this work is to select the optimum solar distillation unit in Basrah City which is located in south of Iraq (longitude $47^{\circ} 45^{\prime} 06.45^{\prime \prime} \mathrm{E}$, latitude $30^{\circ} 33^{\prime} 56.26 " \mathrm{~N}$ ), and several attempts have been made to use cheaper available materials, where these materials are assembled in the laboratory of Solar Energy in Physics Department University of Basrah.

\section{Experimental Setup}

In this work, three asymmetric single basin solar stills with a same sizes were manufactured. The shallow basin made up of aluminum plate was placed inside the outer box. The outer box made by glass. These solar stills are similar in measurements and sizes but they are differ in the way of supplying their basins with brackish water. Also two flat plate collectors were constructed. Three different units of solar distillation (M1,M2 and M3) were obtained by assembling the stills and solar collectors as shown below :

The first solar unit M1 (asymmetrical solar still); the first solar unit for distillation water in this work is an asymmetric slope basin type solar still. This still was constructed from glass where the base of the solar still has a thickness of (0.6) $\mathrm{cm}$, length of $(66) \mathrm{cm}$, and width of $(60) \mathrm{cm}$. A hole of $(0.8)$ $\mathrm{cm}$ diameter was drilled in the right side of base at a distance (4) $\mathrm{cm}$ from the edge for outlet the produced distill water through a copper tube. The walls and the covers of the stills are made of glass thickness of $(0.4) \mathrm{cm}$ and with dimensions. A small copper tubes diameter of $(0.95) \mathrm{cm}$ are fixed at the base and the back glass cover in order to outlet and inlet water to the solar stills. The front cover has a hole to insert thermometer to measure the temperature of the water in the basin. A basin was manufactured from aluminum plate thickness of (0.05) cm, length of (50) cm, width of $(50) \mathrm{cm}$ and high of (2) $\mathrm{cm}$. This basin was installed inside the still at height of $(0.4) \mathrm{cm}$ from the still base to allow the condensing water to flow under it to the hole and then to the distilled water vessel. A matt black paint is used to paint the basin to increase the temperature of the water in the basin by absorbing all the incident solar radiation. This still is provided with brackish water directly from external tank. Idle water cooler was used as external tank with a capacity of (20) liter in order to control the level of water at the basin, where the depth of water at the basin is (1) $\mathrm{cm}$, as shown in figure (2).

The second unit (M2) ( M1 coupled with flat plate collector ); this unit is a unit M1 coupled with flat plate collector (Z1). In this unit, the brackish water is coming from the external tank goes through flat plate collector (Z1) and then goes to the basin. The flat plate collector has been constructed from a zigzag copper tube (diameter of 0.9525 
$\mathrm{cm}$ and length of $757 \mathrm{~cm}$ ) installed on copper plate (with length of $100 \mathrm{~cm}$, width of $50 \mathrm{~cm}$ and thickness of $0.05 \mathrm{~cm}$ ) inside insulated plywood box (thickness of $1 \mathrm{~cm}$, length of $112 \mathrm{~cm}$, width of $62 \mathrm{~cm}$ and high of $15 \mathrm{~cm}$ ) as shown in figure (3). Inclination angle of the solar collector was changed manually between 15 degrees in summer and 45 degrees in winter.

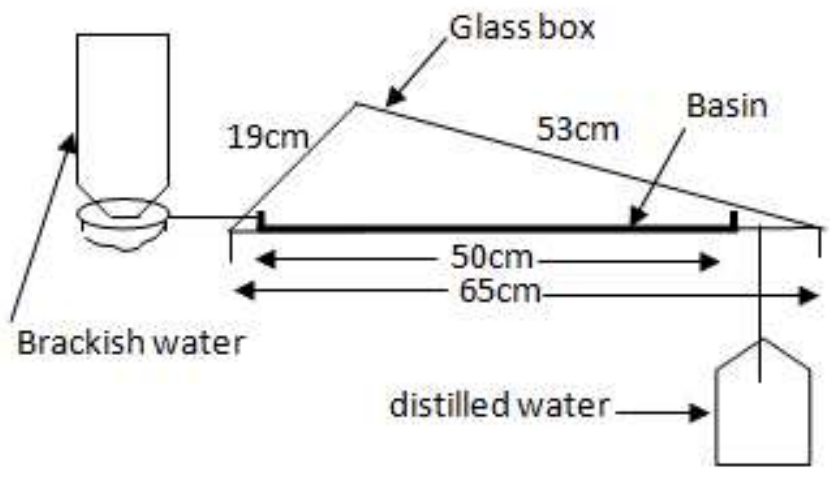

(a)

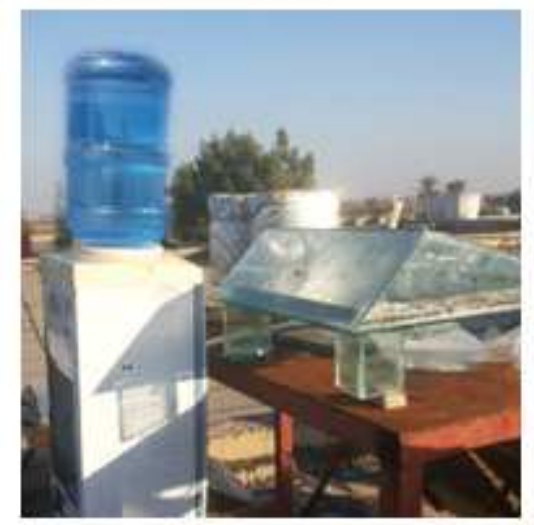

(b)

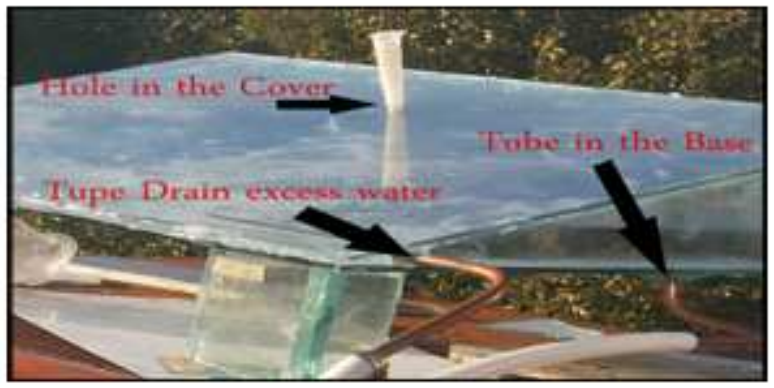

(c)

Fig. (2). (a) Schematic diagram of an asymmetric basin type solar still and experimentally setup of M1. (b) A photograph for distillation unit M1. (c) Shows hole in the cover, drain excess water and tube in the base.

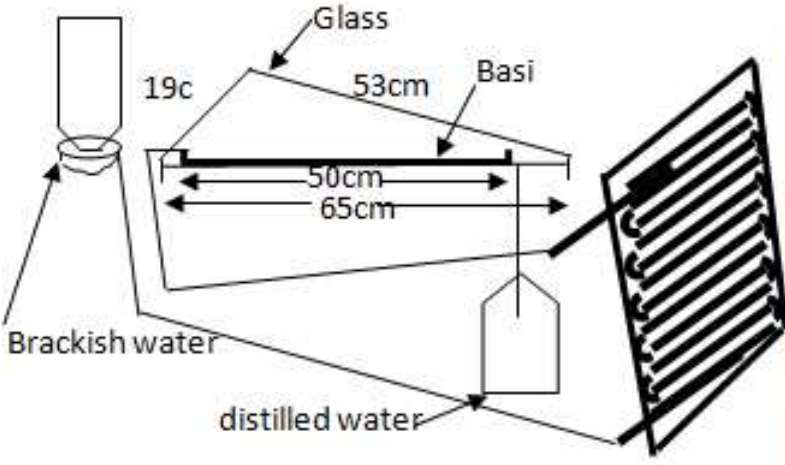

(a)

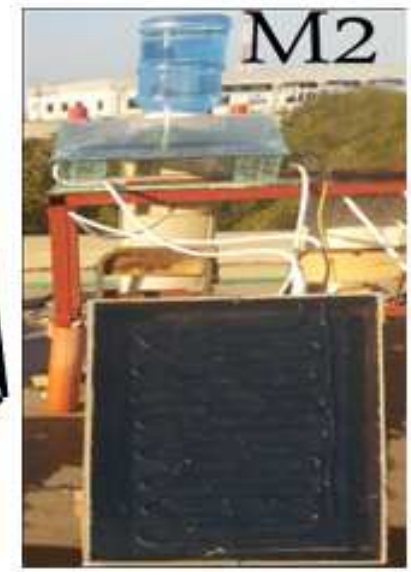

(b)

Fig. (3). (a) Schematic diagram of an asymmetric basin type solar still and experimentally setup of M2. (b) A photograph for experimentally setup of solar distillation M2.

The third unit (M3); This solar distillation unit is different from that for (M2) by placing an internal condenser from copper tube diameter of $(0.79) \mathrm{cm}$ and length of $(285) \mathrm{cm}$ on the inner glass walls of the still to enhance the condensing rate by releasing the latent heat of evaporation as shown in figure (4). In this type the water flow from external tank to 
the condensing tube and go through the flat plate collector and finally to the basin of the still, as shown in figure (4).

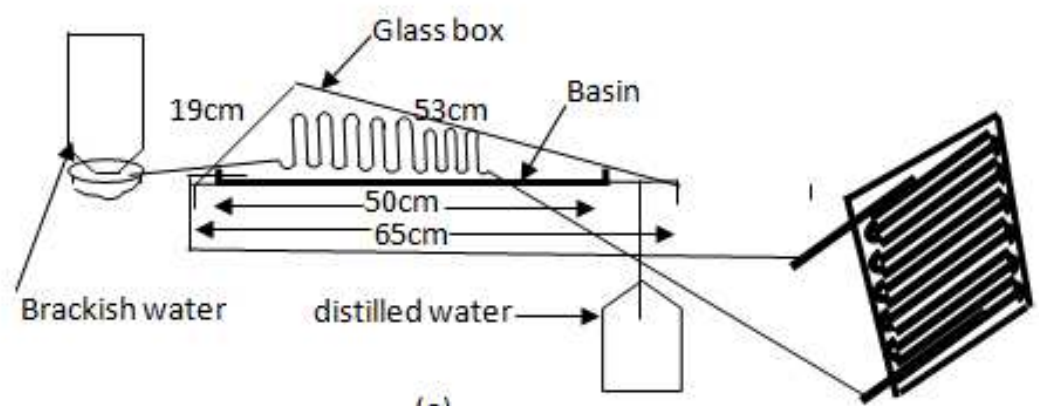

(a)

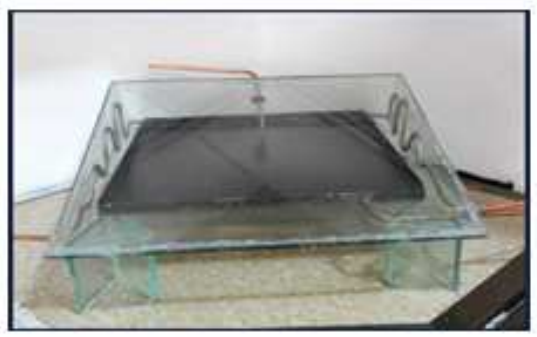

(b)

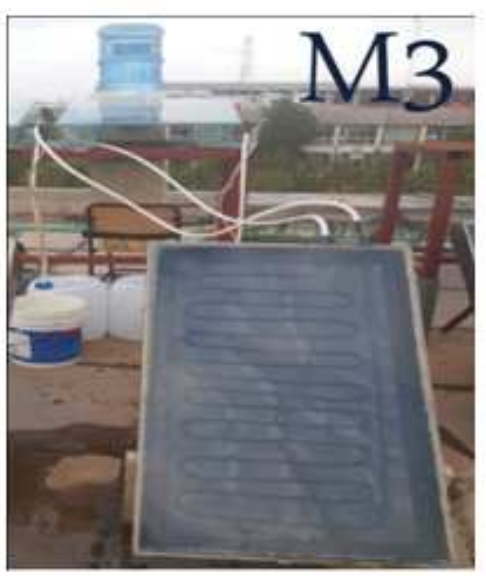

(c)

Fig. (4). (a) Schematic diagram of an asymmetric basin type solar still and experimentally setup of M3. (b) A photograph shows the copper tube inside the still. (c) A photograph for the experimentally setup of M3.

\section{Results and Discussion}

Figures (5) \& (6) shows the monthly mean productivity for solar distillation units in the period of measurements which begin from (December 2013) to (May 2014). It is clearly shown that the productivity of unit (M3) is the best one, the unit (M2) was in the second rank and M1 was at the last rank .

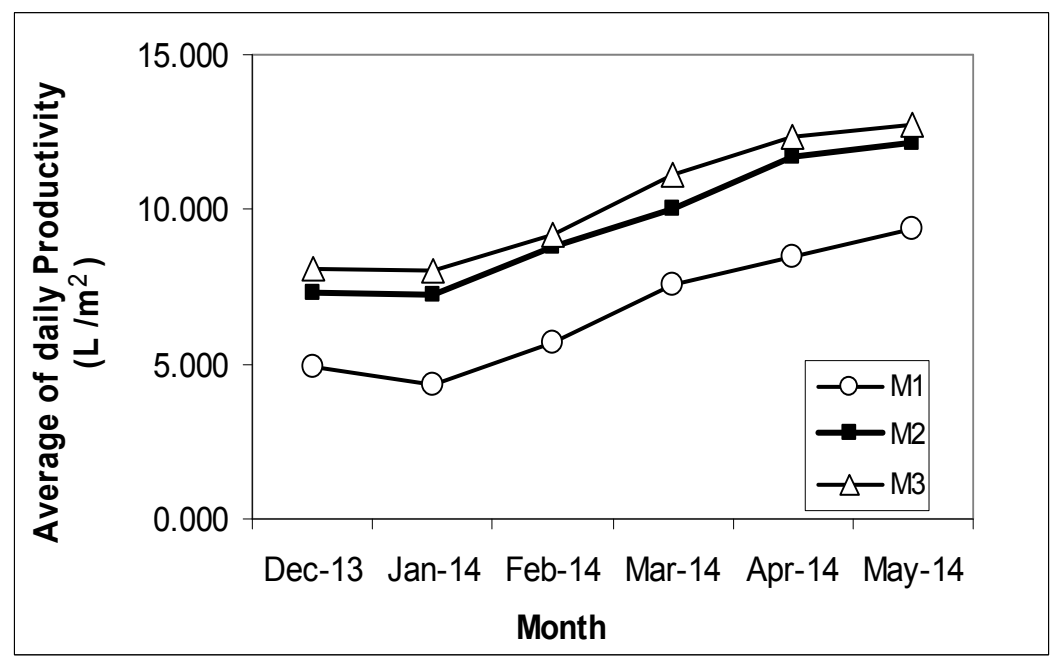

Fig. (5). The average of daily productivity for the Month (December- 2013 to May-2014).

From figures 5 and 6 , it is clear that the second unit M2 to be more productive than the first unit M1 due to the effect of adding the flat plate solar collector to the solar still, which lead to rise the basin water temperature, so there is increasing 
in the evaporation, condensation and production rate with respect to the basin water temperature means the higher basin water temperature, higher rate of evaporation and higher the distillate output from the solar still. This high productivity is gained by the solar still coupled with flat plate collector. This is explained by fact that when temperature of water inside the tube will heated by the incoming solar radiation, hence the water temperature will be increased and such kind of preheated water will be used in solar still, so less heat is required to evaporate the water into steam and higher distillate output is enhanced by solar still.

In the M3 unit in addition to what has been mentioned in $\mathrm{M} 2$, the copper tube which have been installed inside the solar still helps to realize the latent heat of vaporization and acquired by the water passing through it, which helps to increase the condensation process within the still and then the hot water goes to the solar collector and increases its temperature more then enters the basin, which became ready to evaporation process. The average daily productivity of unit M3 is more than M2 by $8 \%$ and by $52 \%$ more than M1.

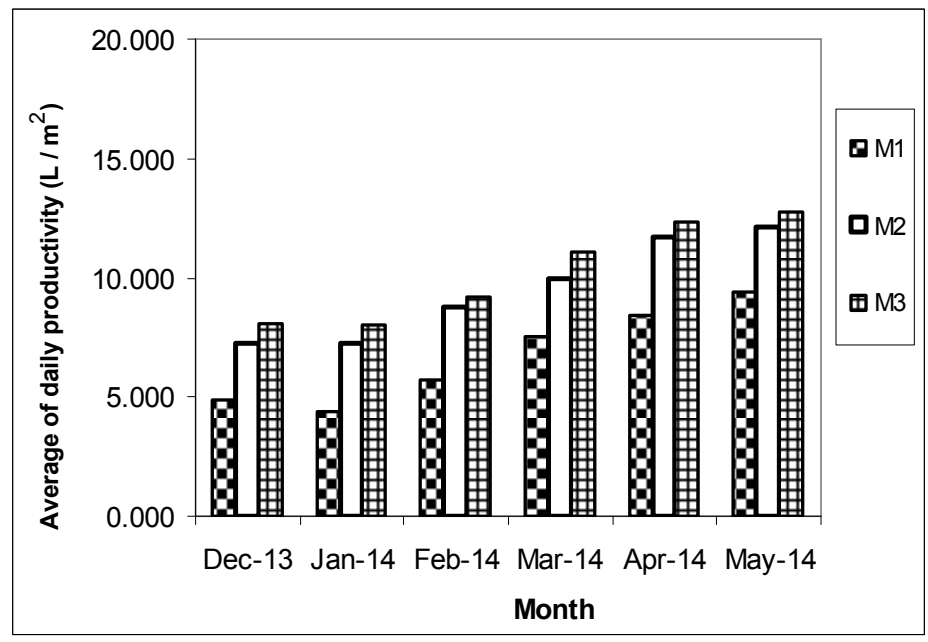

Fig. (6). Average daily Production for different months of the year for the three solar distillation (M1,M2 and M3)

\section{References}

[1] Hitesh N. Panchal et al, A comparative analysis of single slope solar still coupled with flat plate collector and passive solar still, IJRRAS 7 (2) May 2011.

[2] Khalifa, A.J.N., A.M. Hamood Performance Correlations for Basin-type Solar Stills. Desalination 249 (2009) 24-28

[3] Omar O. Badran, Mazen M. Abu-khader, "Evaluating thermal performance of a single slope solar still" , Heat And Mass Transfer, No.43, pp. 985-995, 2007.

[4] Al Hayek I and Bardan O O, "The effect of using different designs of solar stills on water distillation" , Desalination, No.150, pp.230-250, 2004.

[5] M. Koilraj Gnanadason et al, "Comparison of Performance Analysis between Single Basin Solar Still made up of Copper and GI", International Journal of Innovative Research in
Science, Engineering and Technology Vol. 2, Issue 7, July 2013.

[6] Al-Kharabsheh S.\& Goswami D. Y. Theoretical Analysis of a Water Desalination System Using Low Grade Solar Heat. Journal of Solar Energy Engineering MAY, Vol. 126, 2004.

[7] Tiwari A.K. \& Tiwari G.N. Thermal modeling based on solar fraction and experimental study of the annual and seasonal performance of a single slope passive solar still: The effect of water depths. Desalination 207,pp. 184-204, 2007.

[8] Kalogirou S. A. Seawater desalination using renewable energy sources. Progress in Energy and Combustion Science 31,pp. 242-281,2005.

[9] T. Rajaseenivasan, P. Nelson Raja, K. Srithar. An experimental investigation on a solar still with an integrated flat plate collector, Desalination 347 (2014) 131-137.

[10] Mohamed A. Eltawil , Z.M. Omara. Enhancing the solar still performance using solar photovoltaic, flat plate collector and hot air, Desalination 349 (2014) 1-9. 